\title{
Conjunctival Melanoma TNM Finding v8
}

National Cancer Institute

\section{Source}

National Cancer Institute. Conjunctival Melanoma TNM Finding v8. NCI Thesaurus. Code C140556.

A finding about one or more characteristics of conjunctival melanoma, following the rules of the TNM AJCC v8 classification system. This classification system applies to melanomas arising from the bulbar and palpebral conjunctiva and from the caruncle. Primary eyelid melanomas are staged according to the classification for melanoma of the skin and secondary involvement of the conjunctiva by extraocular uveal melanoma is staged according to the classification for uveal melanoma. There is no proposal for anatomic stage and prognostic groups for conjunctival melanoma. (from AJCC 8th Ed.) 